Article

\title{
Accumulation and Biotransformation of Dinophysis Toxins by the Surf Clam Mesodesma donacium
}

\author{
Juan Blanco ${ }^{1, *} \mathbb{E}$, Gonzalo Álvarez ${ }^{2,3, *}$, José Rengel ${ }^{2}$, Rosario Díaz ${ }^{2}$, Carmen Mariño ${ }^{1}$, \\ Helena Martín ${ }^{1}$ and Eduardo Uribe 2 ii \\ 1 Centro de Investigacións Mariñas, Xunta de Galicia, Pedras de Corón S/N, 36620 Vilanova de Arousa, Spain; \\ maria.carmen.marino.cadarso@xunta.gal (C.M.); helena.martin.sanchez@xunta.gal (H.M.) \\ 2 Departamento de Acuicultura, Universidad Católica del Norte, Larrondo 1281, Coquimbo, Chile; \\ jrengel@unc.cl (J.R.); rdiaz@ucn.cl (R.D.); euribe@ucn.cl (E.U.) \\ 3 Centro de Investigación y Desarrollo Tecnológico en Algas (CIDTA), Facultad de Ciencias del Mar, \\ Larrondo 1281, Universidad Católica del Norte, Coquimbo, Chile \\ * Correspondence: juan.carlos.blanco.perez@xunta.gal (J.B.); gmalvarez@ucn.cl (G.Á.)
}

Received: 31 May 2018; Accepted: 27 July 2018; Published: 4 August 2018

\begin{abstract}
Surf clams, Mesodesma donacium, were shown to accumulate toxins from Dinophysis acuminata blooms. Only pectenotoxin 2 (PTX2) and some of its derivatives were found, and no toxins from the okadaic acid group were detected. PTX2 seems to be transformed to PTX2 seco-acid (PTX2sa), which was found in concentrations more than ten-fold those of PTX2. The seco-acid was transformed to acyl-derivatives by esterification with different fatty acids. The estimated amount of these derivatives in the mollusks was much higher than that of PTX2. Most esters were originated by even carbon chain fatty acids, but some originated by odd carbon number were also found in noticeable concentrations. Some peaks of toxin in the bivalves did not coincide with those of Dinophysis abundance, suggesting that there were large differences in toxin content per cell among the populations that developed throughout the year. The observed depuration (from the digestive gland) was fast (more than $0.2 \mathrm{day}^{-1}$ ), and was faster for PTX2 than for PTX2sa, which in turn was faster than that of esters of PTX2sa. PTX2 and PTX2sa were distributed nearly equally between the digestive gland and the remaining tissues, but less than $5 \%$ of the palmytoyl-esters were found outside the digestive gland.
\end{abstract}

Keywords: pectenotoxins; surf clam; accumulation; biotransformation; depuration

Key Contribution: Mesodesma donacium accumulates only PTX2, and no other pectenotoxin or toxin of the okadaic acid group from Dinophysis acuminata blooms in northern Chile, suggesting that only this toxin is produced by D. acuminata from the area. This compound is quickly transformed to PTX2sa and to acyl-ester, and also depurates quickly.

\section{Introduction}

Toxins produced by the dinoflagellate genus Dinophysis frequently accumulate in bivalves making them unsafe for human consumption and leading to closures of fisheries or marketing of aquaculture products. The impacts of these toxins are widely distributed across the oceans, but some areas are particularly affected, as is the case in Southern Chile and North-Western Spain [1-8].

Species of the genus Dinophysis are known to produce two different groups of toxic compounds: toxins of the okadaic acid (OA) group and pectenotoxins (PTX) [7]. The production of one or both types of toxins is known to be species-specific, but important strain variation exists. Some species produce only pectenotoxins (Figure 1) while others usually produce toxins of both groups, although in 
some cases, with a low relative proportion of pectenotoxins [7]. While the toxins of the OA group have caused numerous intoxications [9], there is no evidence that PTXs are toxic for humans by oral exposure [10]. However, due to their toxicity by intraperitoneal injection (and some contradictory results about the effects of oral administration) in mice and rats, some regulatory systems, such as the European one, still maintain quarantine levels for these compounds [11,12], with a noticeable incidence for products that target these markets.

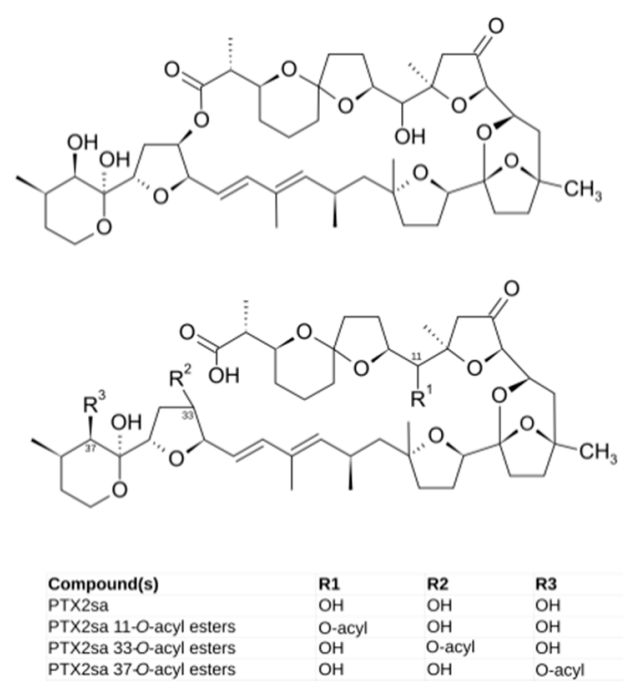

Figure 1. PTX2 (upper structure) and PTX2 seco-acid (PTX2sa) and its acyl esters (lower structure).

In many bivalves, the accumulated toxins of the okadaic acid (OA) group are transformed to 7-O-acyl derivatives (generically known as DTX3) by esterification with fatty acids of different carbon chain length [13-15]. Very likely this is the main route for the elimination of those compounds from the bivalves. Less information exists for pectenotoxins, but it is known that they can be enzymatically transformed to their corresponding seco-acid (by opening the macro-ring of the molecule) in the digestive system of some mollusks [16]. These seco-acids can be esterified by fatty acids (as in the case of the toxins of the OA group) at least in the mussel Mytilus edulis [17] and in an Australian clam (probably Plebidonax deltoids) [14], suggesting that this can also be a depuration route.

In the northern region of Chile, the impact of the toxins produced by Dinophysis is less than in the south, but some closures, mostly of the economically important aquaculture of the pectinid Argopecten purpuratus, have taken place, as happened in 2005 due to a bloom of Dinophysis acuminata [18]. In that case D. acuminata was shown to have an atypical toxin profile, producing only pectenotoxins, without traces of toxins of the okadaic acid group. D. acuminata had been shown to be present in the north of Chile many years earlier [19-21], and could be assumed to be persistent in the area. DSP harvesting closures in the area, notwithstanding, were not needed until October 2005 [18], suggesting that toxin production was low, or that the toxins produced were quickly degraded or depurated from the bivalves in the area.

In this work, we studied D. acuminata populations, and the accumulation in the surf clam Mesodesma donacium of the toxins produced by this species in Coquimbo Bay, a significant fishing area for this economically important species. The objectives of the study were: (a) to obtain the profile of accumulated toxins; (b) to check if the accumulated toxin follows the D. acuminata cell abundance; (c) to obtain an estimate of the depuration rate of the toxins involved; and d), to gather knowledge about the possible transformations that take place in the bivalve. 


\section{Results}

\subsection{Abundance and Composition of Dinophysis Populations}

Dinophysis populations were always present in the area and were dominated by Dinophysis acuminata. Its abundance was generally low, with cell concentrations below 300 cells $\mathrm{L}^{-1}$ in $75 \%$ of the sampled weeks. However, some blooms, with abundances over 900 cells $\mathrm{L}^{-1}$ were recorded in April 2009, and in January and February 2010, reaching a maximum of 2100 cells $\mathrm{L}^{-1}$. On some occasions, Dinophysis caudata and $D$. tripos were detected but only in net samples (with very low concentrations) and their populations could not be quantified. The cells of Dinophysis acuminata were almost oval in shape with the left sulcal list well developed and extending about one-half to two-thirds of the cell length (Figure 2). The thecal plates that constitute the hypotheca were covered with circular areolae. The antapex of the cells was rounded, and in some cells two to four small knob-shaped posterior protrusions were found. The length (L) of the cell was $47.61 \pm 3.87 \mu \mathrm{m}$ and the dorso-ventral width (W) was $34.69 \pm 3.47 \mu \mathrm{m}$, while the $\mathrm{L} / \mathrm{W}$ ratio was 1.38 .

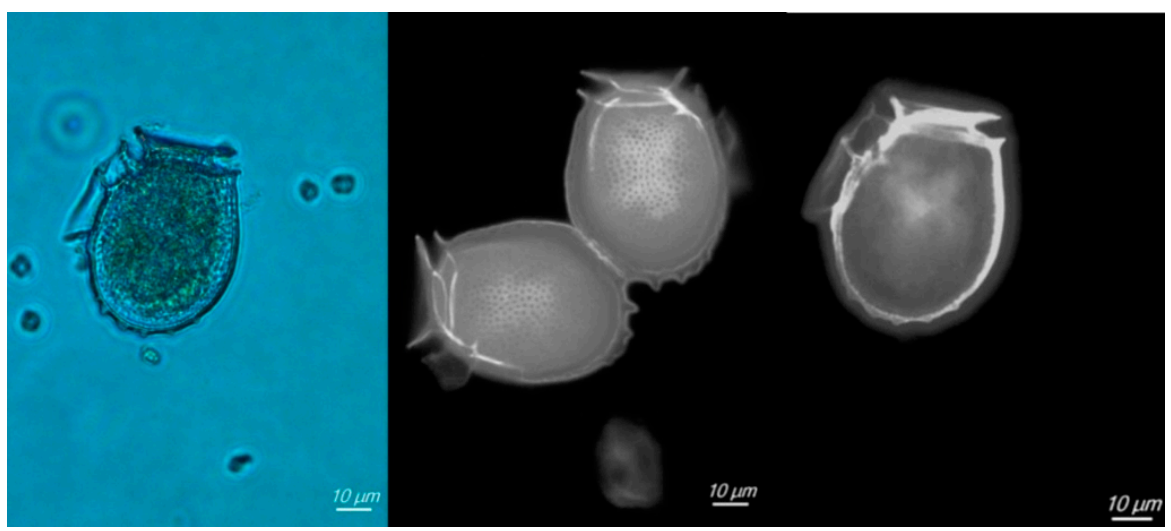

Figure 2. Phase contrast (left) and fluorescence photomicrographs of Calcofluor stained (right) Dinophysis acuminata cells from samples of the study.

\subsection{Toxin Profiles}

OA, DTX1 or DTX2 were not detected in either the raw or the hydrolyzed samples, in this study. The only PTX found was PTX2, which was accompanied by its seco-acid and by acyl-esters of its seco-acid (Figures 3 and 4). None of the other monitored PTX compounds (Table 1) were found. The main esters of PTX2-sa found were produced by esterification with palmitic acid (C16), but other esters-from fatty acids with even carbon numbers (mainly C16:1, C14:0, C18:0, C18:1, C10:5) and with odd carbon numbers (mainly, C15:0, C17:0 and C17:1)—were also found (Figure 4). The detected acyl-esters seem to be mostly products of the esterification of the hydroxyl groups at C33 and/or C37, as their fragmentation pattern presented relevant peaks at $m / z 823$, which is typical of these types of esters (Figure 5). Additional small peaks also appeared when the product $m / z 1061.5$ was monitored, probably due to the presence of C11 esters. A regression of the signals of $m / z 823$ and 1061 in all measured samples gave an $\mathrm{R}^{2}$ of 0.999 , indicating that the contribution of the C11 esters (associated with $m / z 1061$ but not with $m / z$ 823) was very small. 


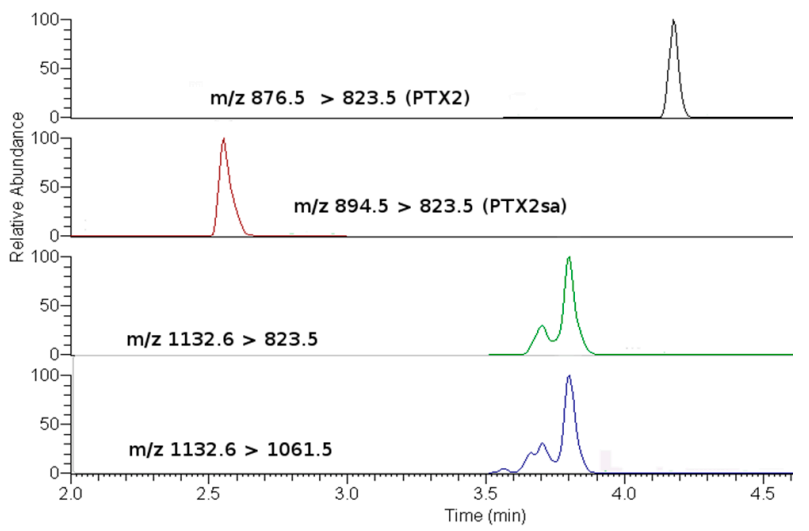

Figure 3. Chromatograms of the main pectenotoxin (PTX) analogs detected (sample of the digestive gland on 12 August 2009). The two lower chromatograms correspond to transitions of palmytoyl-esters of PTX2sa. The upper one of these is more affected by C33 and C37 esters and the lower one of these is also affected by $\mathrm{C} 11$ esters.

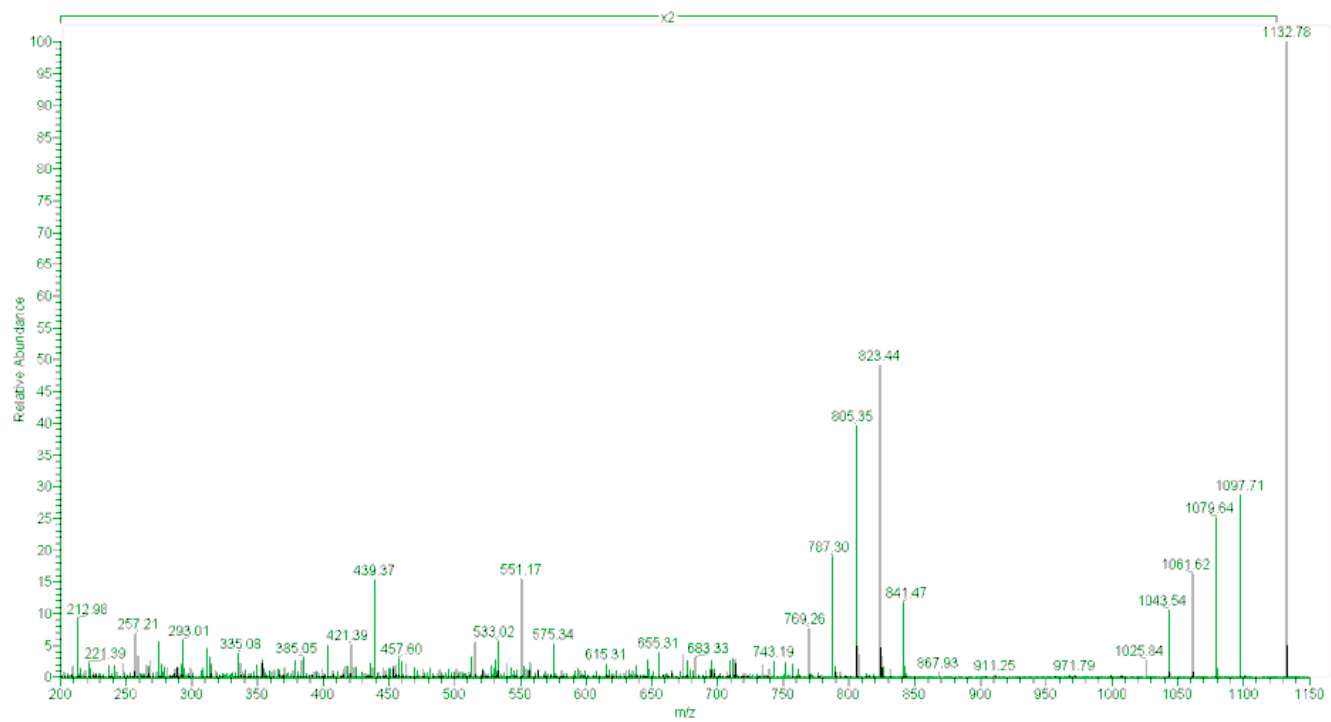

Figure 4. Fragmentation spectrum of palmitoyl-PTX2sa (main peaks).

Table 1. Transitions used to identify and quantify the compounds studied $(\mathrm{CE}=$ Collision Energy $(\mathrm{V}))$.

\begin{tabular}{cccc}
\hline Reference & Parent & Product & CE \\
\hline \multicolumn{4}{c}{ PTXs method } \\
OA_DTX-2 & 803.5 & 255.2 & 48 \\
OA_DTX-2 & 803.5 & 563.4 & 43 \\
DTX-1 & 817.5 & 255.2 & 48 \\
DTX-1 & 817.5 & 563.5 & 43 \\
PTX-2 & 876.5 & 805.5 & 23 \\
PTX-2 & 876.5 & 823.5 & 21 \\
PTX1 & 892.5 & 839.5 & 23 \\
PTX6 & 906.5 & 853.5 & 23 \\
PTX12 & 874.5 & 821.5 & 23 \\
PTX2sa & 894.5 & 823.5 & 21 \\
PTX2sa & 894.5 & 805.5 & 21 \\
PTX11sa & 910.5 & 179.2 & 50 \\
PTX11sa & 910.5 & 137.2 & 50 \\
C16-PTX2sa C 33,37 & 1132.6 & 823.5 & 23 \\
C16-PTX2sa C 11 & 1132.6 & 1061.5 & 23 \\
\hline
\end{tabular}


Table 1. Cont.

\begin{tabular}{cccc}
\hline \multicolumn{1}{c}{ Reference } & Parent & Product & CE \\
\hline \multicolumn{4}{c}{ Acyl derivatives } \\
method \\
C14:0-PTX2sa & 1104.6 & 823.5 & 23 \\
C15:0-PTX2sa & 1118.6 & 823.5 & 23 \\
C16:1-PTX2sa & 1130.6 & 823.5 & 23 \\
C16:0-PTX2sa & 1132.6 & 823.5 & 23 \\
C17:1-PTX2sa & 1144.6 & 823.5 & 23 \\
C17:0-PTX2sa & 1146.6 & 823.5 & 23 \\
C18:5-PTX2sa & 1150.6 & 823.5 & 23 \\
C18:4-PTX2sa & 1152.6 & 823.5 & 23 \\
C18:3-PTX2sa & 1154.6 & 823.5 & 23 \\
C18:2-PTX2sa & 1156.6 & 823.5 & 23 \\
C18:1-PTX2sa & 1158.6 & 823.5 & 23 \\
C18:0-PTX2sa & 1160.6 & 823.5 & 23 \\
C20:5-PTX2sa & 1178.6 & 823.5 & 23 \\
C20:4-PTX2sa & 1180.6 & 823.5 & 23 \\
C20:2-PTX2sa & 1184.6 & 823.5 & 23 \\
C20:1-PTX2sa & 1186.6 & 823.5 & 23 \\
C20:0-PTX2sa & 1188.6 & 823.5 & 23 \\
C22:6-PTX2sa & 1204.6 & 823.5 & 23 \\
\hline
\end{tabular}
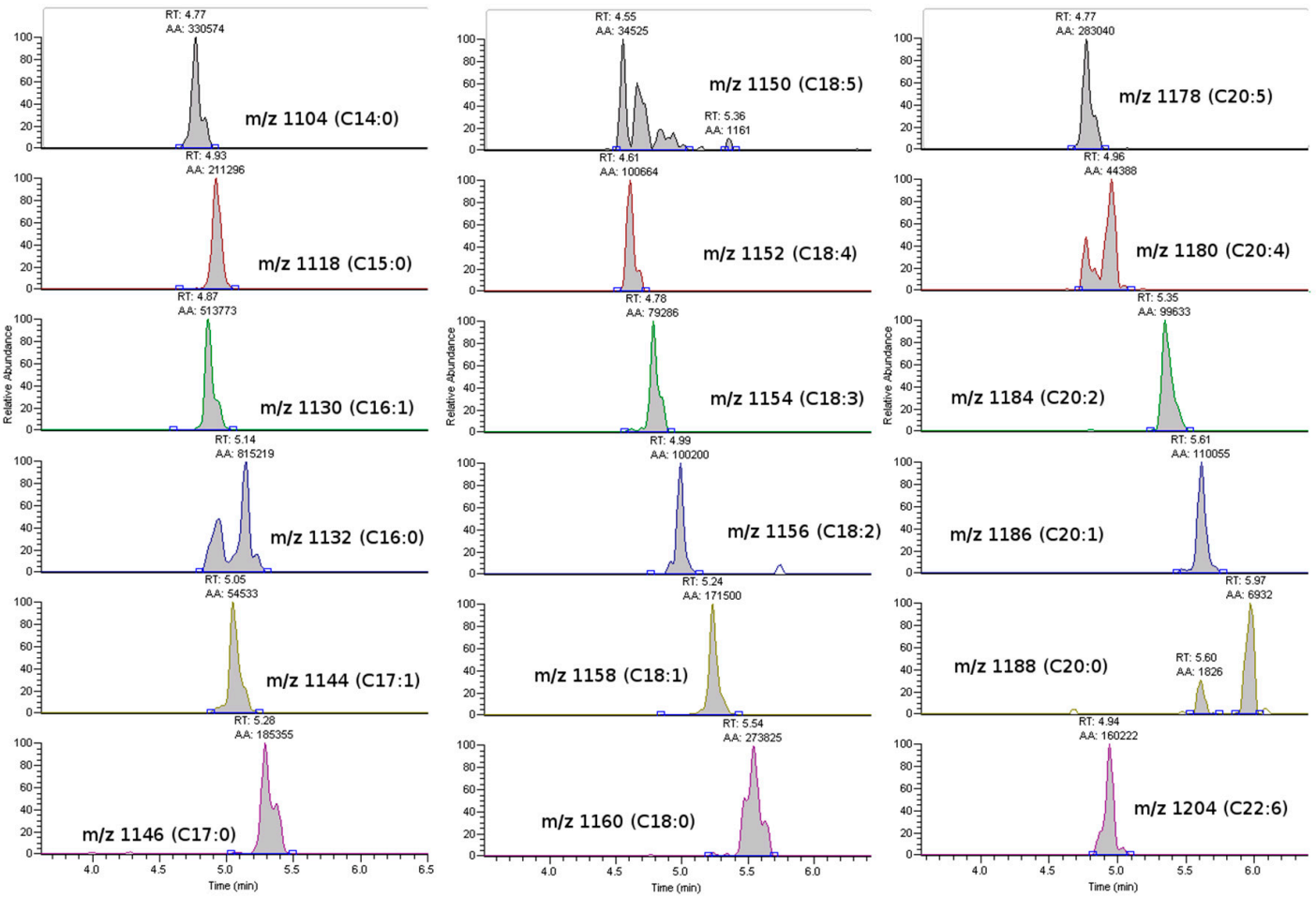

Figure 5. Chromatograms of the main acyl-derivatives of PTX2sa in the sample corresponding to the digestive gland of the Mesodesma donacium taken on 12 August 2009. $\mathrm{m} / \mathrm{z}$ numbers are the parent masses (product $m / z=823$ ) corresponding to esters of PTX2sa with fatty acids of the indicated chain.

Several esters, and perhaps several conformational isomers of them, for each fatty acid may be involved as they were not resolved as a unique chromatographic peak, as shown for the esters with palmitic acid (Figure 3).

PTX2 seco-acid (PTX2sa) concentrations were much higher than those of PTX2. Even though the precise contribution of PTX2sa could not be determined because of the lack of reference solutions, 
the response in our method (estimated by means of a biotransformation experiment not reported here) was approximately one-third that of PTX2. Taking this into account, the PTX2sa concentrations found were on average nearly 20 -fold and 10-fold those of PTX2, in the digestive gland and in the remaining tissues, respectively.

Assuming that the response of the palmitoyl-esters of PTX2sa detected in the mass spectrometer was the same as that of the unesterified compound, esters (even when only those of palmitic acid were quantified) had, on average, half the concentration of PTX2sa in the digestive gland and were nearly absent from the remaining tissues (Figure 6).

The relationship between the pectenotoxins concentration and those of its derivatives was linear and statistically significant, both, in the digestive gland and in the remaining tissues (Supplementary Material).

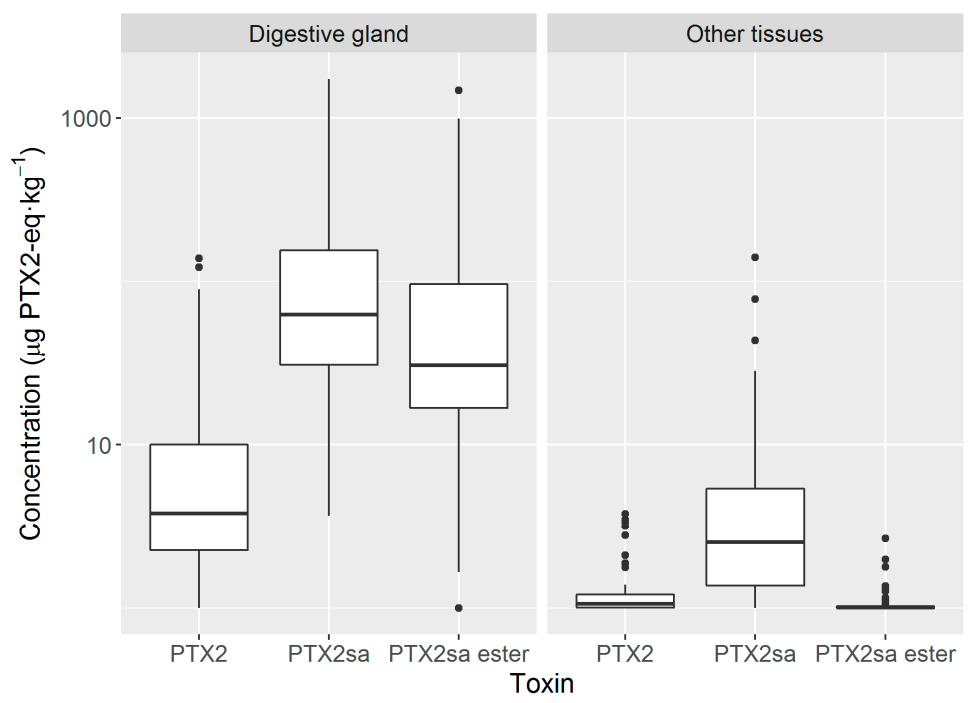

Figure 6. Concentration of the studied toxins in digestive gland and remaining tissues of Mesodesma donacium $($ PTX2sa ester = palmytoyl-PTX2sa). The limits of each box correspond to the $75 \%$ and $25 \%$ quartiles. The central horizontal line inside the box is the median. The extremes of the vertical lines are the extreme observations excluding the outliers and the isolated dots are outliers.

\subsection{Anatomical Distribution of Toxins}

The concentrations of all toxins studied were much higher in the digestive gland than in the remaining tissues (Figure 7a). The concentrations of PTX2 and PTX2sa in the digestive gland were approximately 10-fold those in other tissues, but the difference was even more important for esters which were more than 300-fold more concentrated in the digestive gland (Figure 7a).

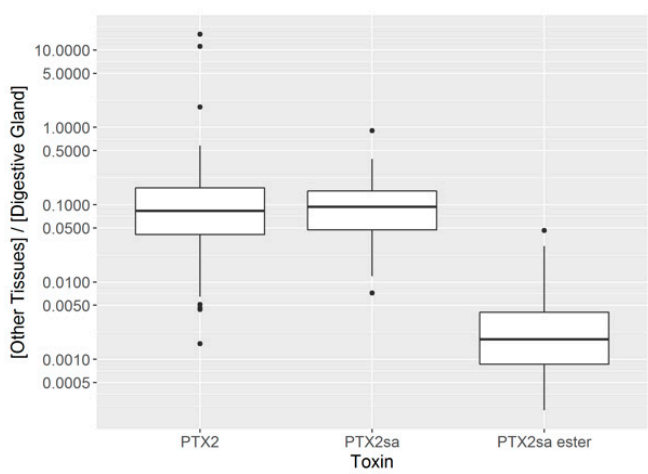

(a)

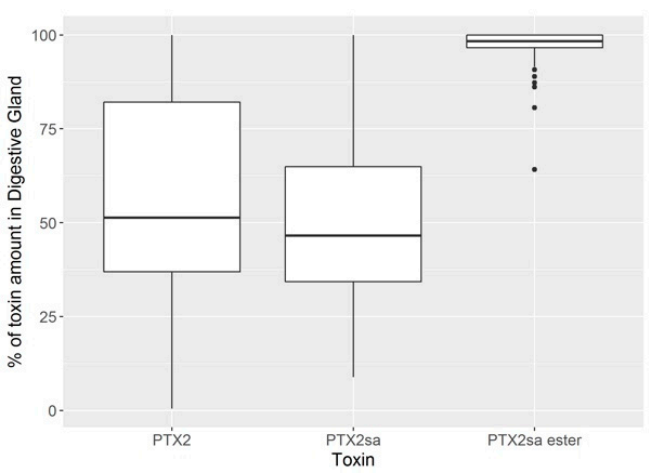

(b)

Figure 7. (a) Ratio between concentration of the toxins in digestive gland and other tissues (left panel) and (b) percentage of the total toxin burden in the digestive gland (right panel). 
The amounts of PTX2 and PTX2sa were evenly distributed between the digestive gland and the remaining tissues (with slightly less PTX2sa in the remaining tissues) (Figure $7 \mathrm{~b}$ ), but nearly all esters were located in the digestive gland (with significant differences between esters and the other two toxins, but not between PTX2 and PTX2sa).

\subsection{Dinophysis Abundance and Toxin Concentration}

Dinophysis abundance was generally low, exceeding 500 cells $\mathrm{L}^{-1}$ on only a few occasions. The maximum weekly mean of cell concentration attained was 1825 cells L $^{-1}$ (Figure 8). The time-course of toxin concentration of $M$. donacium in the digestive gland showed three main peaks, which took place at the same time for the PTX1, PTX2sa and PTX2sa esters. In general (when records of both, toxins and cells were available) the peaks of $D$. acuminata abundance and toxin concentration in surf clams did not coincide.

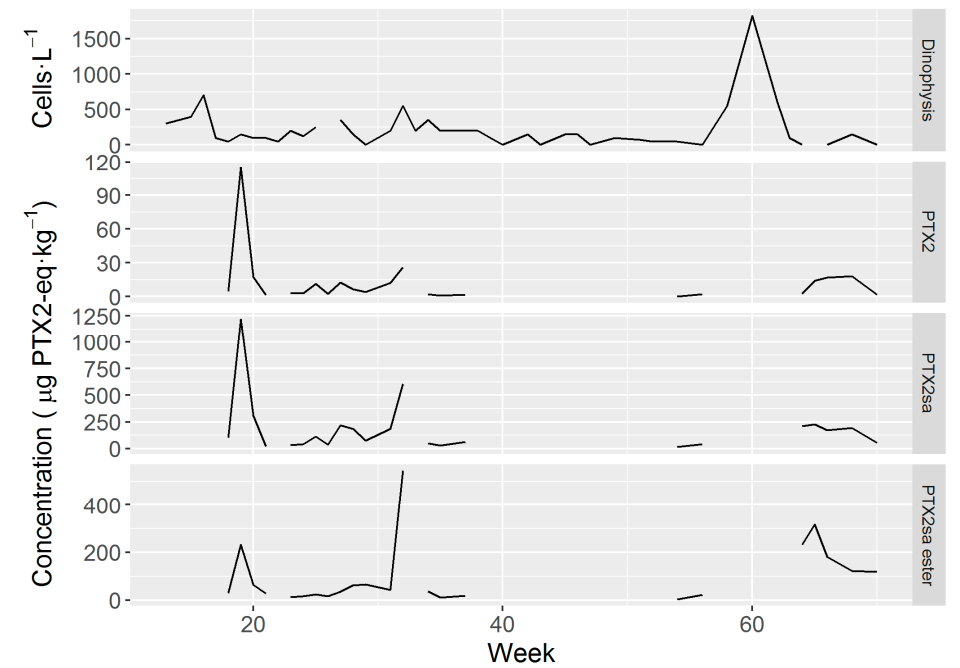

Figure 8. Dinophysis acuminata abundance and average weekly toxin concentrations in M. donacium in samples from Bahía Coquimbo. Periods not connected by lines correspond to weeks in which samples could not be obtained.

\subsection{Depuration Rates}

The estimated depuration rates (Figure 9) were higher for PTX2 than for PTX2-sa and PTX2-sa esters. The average values were high at $0.3,0.23$ and 0.2 day $^{-1}$, respectively.

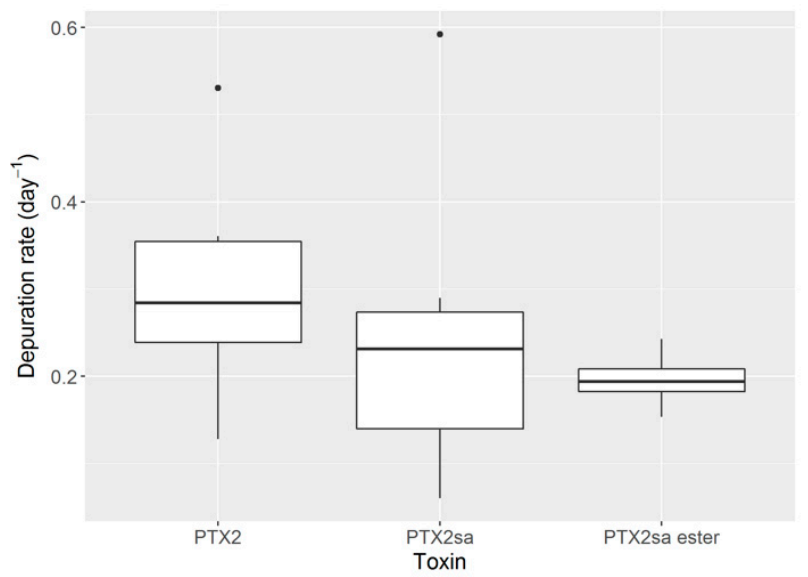

Figure 9. Estimated depuration rates for PTX2 and its derivatives. 


\section{Discussion}

In Chile, the presence of Dinophysis acuminata has been described in several distinct geographical locations. In northern Chile this species has been described between $18{ }^{\circ} \mathrm{S}$ and $33^{\circ} \mathrm{S}$ [18-22]. The taxonomic examination of specimens from phytoplankton net samples revealed that the main morphological features correspond to descriptions of this species given by Faust and Gulledge [23]. In relation to cell size, the length is consistent with measures given by Faust and Gulledge [23] (38-58 $\mu \mathrm{m})$, Lebour [24] (38-51 $\mu \mathrm{m})$, Dodge and Hart-Jones [25] (38-58 $\mu \mathrm{m})$, Olenina et al. [26] (38-58 $\mu \mathrm{m})$ and Reguera [27] (44-58 $\mu \mathrm{m})$. However, our cells were larger than those reported by Sar et al. [28] (31.5-38 $\mu \mathrm{m})$. In relation to cell width, our measures are consistent with the values reported by Olenina et al. [26] (30-38 $\mu \mathrm{m})$, Faust and Gulledge [23] (30-40 $\mu \mathrm{m})$ and Reguera [27] (24-43 $\mu \mathrm{m})$.

Dinophysis acuminata was found to be persistent in the area, but without attaining high cell concentrations. This finding seems to be consistent with observations that the species is common in Northern Chile [18-21], but that it seldom results in market closures of fisheries or aquaculture products [18].

The toxin profiles observed in $M$. donacium, with a complete absence of toxins of the okadaic acid group, suggest that the lack of these toxins in D. acuminata from the area found in a bloom in 2005 by Blanco, Alvarez and Uribe [18], was not a special case but rather a general characteristic of this species in the area. The diversity of toxins and derivatives of the PTX group was very limited. Only PTX2 and some of its derivatives in the form of seco-acid and seco-acid esters were found, suggesting that the Dinophysis populations contain only PTX2, as PTX2-sa (as also seems to be the case on the Argentinian coast [29]) and its esters are formed by the action of the bivalve [16,17,30-32]. Apart from Mytilus edulis $[14,17]$ and an "Australian clam" (cited by Doucet et al. [14] without specifying the species, but which was probably Plebidonax deltoides as high accumulations of PTX2sa had been found in this species in the area $[7,33])$, Mesodesma donacium is the first species in which esters of PTX2sa have been found, suggesting that this transformation could be general in molluscs. In other bivalve species, such as Patinopecten yessoensis, PTX2 undergoes an oxidation that yields PTX6 as the final product and PTX1 as intermediate one [34,35], but neither PTX6 nor PTX1 have been found in M. donacium which means that that oxidation route that generates these derivatives is not active in the species.

The fact that the observed peaks of cell abundance did not produce equivalent peaks of pectenotoxins in $M$. donacium suggests that there were substantial differences in toxin/cell among the different $D$. acuminata populations that developed throughout the sampled year. Other causes, such as differences in the availability of the toxic cells to the infaunal populations of the mollusks cannot be discarded. However, downwelling in the area (computed from the wind data of a meteorological station on-shore, data not shown) — the main process that could potentially regulate this availabilitywas not related to the toxin peaks in the clams.

The presence in M. donacium of PTX2, PTX2sa and PTX2sa esters suggests that PTX2 is transformed to PTX2sa and then to PTX2sa esters. The first step (PTX2 to PTX2sa) could take place in the gut, during = the process of extracellular digestion of the ingested phytoplankton, as demonstrated by MacKenzie, Selwood and Marshall [16] for Perna canaliculus but it is possible that the transformation continues once PTX2 is inside the digestive cells as it has also been observed in vitro by treating PTX2 with homogenates [30-32] (or even in cells of other tissues). Esters of PTX2sa should be generated inside the cells as happens with other toxins, such as those of the OA group [13,36,37], brevetoxins [38], spirolides [39], gymnodimines [40], and other lipophilic compounds such as esteroids [41,42]. Very likely the mechanism is a transesterification similar to that found in OA [36,43]. It is clear that this process, in the case of $M$. donacium, only takes place in the digestive gland and not in other tissues, as their content in esters is marginal.

The fact that the apparent depuration rates from the digestive gland are lower as the compound required more transformation steps (PTX2 > PTX2-sa > PTX2-sa esters) can be explained in multiple ways. One possibility is that there were differences in the actual depuration rate of the compounds. A second possibility, which seems more likely, is that the biotransformations altered the estimated 
depuration rates because the losses by depuration of the transformed compound are increased by the amount of compound that is transformed, while those corresponding to the product compound are decreased by the same reason. A combination of the two processes could also take place. A more detailed study involving the analysis of these possibilities would be required to elucidate the precise cause of the observed differences.

The observed depuration rates, even though they are likely to be underestimates (because the cells rarely disappeared from the water), are relatively high in comparison with those of other lipophylic toxins as those in the OA group [44,45]. Mesodesma donacium seems to depurate PTXs much faster than Norwegian mussels and oysters, [46] with estimates of $t_{1 / 2}$ (semidepuration time) of 6-13 days for PTX2 in mussels Mytilus edulis and oysters, while in this study they ranged from 2.3 to 3.1 days, for PTX2 and palmytoyl-PTX2sa, respectively. Notwithstanding this, in a previous study, the estimated depuration rates for PTX2 and PTX2sa from another mussel (Mytilus galloprovincialis), and the cockle Cerastoderma edule, were much higher, ranging from 0.6 to 1.1 and from 1 to 3 day ${ }^{-1}$, respectively $\left(\mathrm{t}_{1 / 2} 1.2-0.6\right.$ days and $0.7-0.2$ days) [47]. Okadaic acid in the same studies was found to depurate from the bivalves at substantially lower rates $[46,47]$.

These high depuration rates indicate that most of the accumulated toxins are likely to have been recently incorporated, and that the levels of these kinds of toxins in $M$. donacium are strongly dependent on the precise nature of the causative organisms.

\section{Materials and Methods}

\subsection{Area of Study, Phytoplankton Sampling, Quantification and Taxonomic Analyses}

Phytoplankton samples were collected periodically (weekly when possible) in Bahía Coquimbo $\left(29^{\circ} 51^{\prime} \mathrm{S}, 71^{\circ} 16^{\prime} \mathrm{W}\right)$ from 1 May 2009 to 28 April 2010, by means of vertical net hauls ( $20 \mu \mathrm{m}$ mesh) and a $10 \mathrm{~m}$ hose, in order to obtain integrated samples of the entire water column. Bahía Coquimbo is a wide bay with a mean depth of $25 \mathrm{~m}$, and is very dynamic, with typical surficial tidal currents of around $10 \mathrm{~cm} \cdot \mathrm{s}^{-1}$ and bottom currents between 4 and $13 \mathrm{~cm} \cdot \mathrm{s}^{-1}$ [48]. The bottom sediment is mostly sand and is sorted by depth, with the finest particles in the deepest locations [49], indicating a high dynamism in the shallow areas. A thermocline sometimes exists, at a depth of $10 \mathrm{~m}$. The phytoplankton samples were obtained from the same location as those of Mesodesma donacium. Two aliquots were preserved-one with formaldehyde 4\% (net hauls) and another with Lugol's iodine (hose)—for taxonomic and quantitative analyses, respectively. Phytoplankton composition, including D. acuminata cells, were routinely identified using an Olympus IX71 epifluorescence inverted microscope and the method describe by Fritz and Triemer [50]. Phytoplankton and D. acuminata cells were quantified using the Utermöhl method, described by Hasle [51], using 10-mL sedimentation chambers with an Olympus IX71 inverted microscope.

\subsection{Shellfish Sampling, Toxin Extraction and Hydrolysis}

Shellfish samples were collected from 1 May 2009 to 28 April 2010 at the same station as the phytoplankton samples, from 10 to $15 \mathrm{~m}$ deep, by means of hookah diving. When possible, a weekly periodicity was maintained. Samples were homogenized and extracted with methanol $100 \%$ at a ratio of 1:4 (weight:volume). Extracts were clarified by centrifugation $(10,000 \times g, 15 \mathrm{~min})$ and then filtered through $0.20 \mu \mathrm{m}$ Clarinert nylon syringe filters (13 mm diameter) (Agela technologies).

In order to check the presence of derivatives of toxins of the okadaic acid group some extracts, selected because of their high PTX2 levels (which could be expected to be correlated with toxins of the OA group), were subjected to alkaline hydrolysis following the standard procedure of the EU Reference Laboratory for Marine Biotoxins [52]. 


\subsection{Toxin Detection and Quantification}

The toxins contained in the extracts were determined by HPLC-MS/MS, with a Thermo Accela chromatographic system (UHPLC) coupled to a Thermo TSQ Quantum Access Max by means of a HESI-II electrospray interface.

Basically, the chromatographic method by Regueiro et al. 2010 [53] was used, but modified in order to use a shorter column and to allow enough time for the elution, not only of the free toxins, but also of their acylated derivatives. Two chromatographic phases were used: $\mathrm{A}=6.7 \mathrm{mM} \mathrm{NH}_{4} \mathrm{OH}$ in MilliQ water (Millipore); and $\mathrm{B}=90 \% \mathrm{ACN}$ with $6.7 \mathrm{mM} \mathrm{NH}_{4} \mathrm{OH}$. First, the sample was injected into an online solid phase extraction (SPE) column (Phenomenex Security Guard $4 \times 2 \mathrm{~mm}$ with phase Gemini-NX C18 (AJO-8367) in an isocratic flow of $90 \% \mathrm{~A}$ and $10 \% \mathrm{~B}$, while the chromatographic column was kept at $80 \% \mathrm{~A}$. After $1.5 \mathrm{~min}$ the system flow was switched (with a Rheodyne 2-position 6-way valve) and the content of the SPE column started to elute to the chromatographic column (Phenomenex Gemini-NX C18 $50 \times 2 \mathrm{~mm} 3 \mu \mathrm{m}$ ). The phase B percentage was raised in a linear manner until reaching $90 \%$ at $\min 3.85$ and maintained at that concentration until min 8.25 when the initial conditions were put in place again and maintained until min 10.5. At min 7.5 the Rheodyne valve was switched again in order to equilibrate the SPE column for the next injection. For detailed analysis of PTX2sa acyl-derivatives the chromatographic gradient was modified by extending it for 3 additional minutes.

The mass spectrometer was operated in positive and negative ionization mode using the following settings: Spray Voltage Positive 3500 V, Negative 3000 V, Sheath Gas Pressure 50, Aux Gas Flow: 5; Vaporizer Temperature: 110; Capillary Temperature 360; Collision Gas Pressure (mTorr): 1.5. For identification and quantification, the transitions given in Table 1 were used.

The toxin concentration in the extracts was quantified by comparing the area or the peaks obtained in the chromatograms with those of certified reference materials obtained from Laboratorio CIFGA, Spain and the NCR, Canada. When those materials were not available-as was the case for PTX2 seco-acid and esters of PTX2 seco-acid-a relative quantification was carried out using the signal of PTX2 as reference.

\subsection{Estimation of Depuration Rates}

Rough estimates of depuration rates were obtained by using concentration values in two consecutive weeks based on the following selection criteria: (a) that the first observation had a high concentration value; (b) that the D. acuminata abundance in the following week was low; and (c) there was no substantial increase of toxin concentration in the third week. This approach would yield underestimated values of the depuration rate as some toxin uptake had taken place during the period for which depuration was estimated. It was assumed that depuration followed an exponential decrease, and the rate for each period was computed as $\operatorname{Ln}[\operatorname{Tox}]_{\text {week } 0}-\left[\operatorname{Tox}_{\text {week } 1}\right) / 7$ days and was expressed as day $^{-1}$.

\subsection{Statistical Analysis}

Regression, correlation and ANOVA analyses were carried out with $R$ [54]. Descriptive statistical plots were built with the ggplot2 package [55].

Supplementary Materials: The following are available online at http:/ /www.mdpi.com/2072-6651/10/8/314/ s1, Raw data of toxin concentration in the extract. Raw data of Dinophysis acuminata cell counts. Figure S1: Relationships between the PTX2 derivatives.

Author Contributions: Conceptualization: J.B., G.Á., E.U. Formal analysis: J.B. Funding acquisition: G.Á., E.U., J.B. Investigation: G.Á., J.R., E.U., R.D., C.M., H.M. Visualization: J.B., G.Á. Writing-original draft: J.B., G.Á. Writing-review and editing: J.B., G.Á., J.R., E.U.

Funding: This research was funded by the "CONICYT + FONDEF/PRIMER CONCURSO INVESTIGACIÓN TECNOLÓGICA TEMATICO EN SISTEMAS PESQUERO ACUICOLAS FRENTE A FLORECIMIENTOS 
ALGALES NOCIVOS FANS IDeA DEL FONDO DE FOMENTO AL DESARROLLO CIENTÍFICO Y TECNOLÓGICO, FONDEF/CONICYT 2017, IT17F10002" and by CIMA (Xunta de Galicia). Gonzalo Álvarez was funded by the CHILEAN NATIONAL COMMISSION FOR SCIENTIFIC AND TECHNOLOGICAL RESEARCH (CONICYT+ PAI/CONCURSO NACIONAL INSERCION EN LA ACADEMIA CONVOCATORIA 2015, 79150008).

Acknowledgments: We would like to thank the Asociación Gremial de Pescadores Artesanales de Caleta Peñuelas A.G., and the Asociación Gremial de Pescadores y Buzos Mariscadores Caleta San Pedro La Serena A.G. for their support.

Conflicts of Interest: The authors declare no conflicts of interest.

\section{References}

1. Guzmán, L.; Campodonico, I. Marea roja en la región de Magallanes. Pub. Inst. Patagon. Ser. Monogr. 1975, 9, 44.

2. Lembeye, G.; Yasumoto, Y.; Zhao, J.; Fernández, R. DSP outbreak in Chilean fjords. In Toxic Phytoplankton Blooms in the Sea; Smayda, T.J., Shimizu, Y., Eds.; Elservier: Amsterdam, The Netherlands, 1993; pp. 525-529.

3. Zhao, J.; Lembeye, G.; Cenci, G.; Wall, B.; Yasumoto, T. Determination of okadaic acid and dinophysistoxin-1 in mussels from Chile, Italy and Ireland. In Toxic Phytoplankton Blooms in the Sea; Smayda, T.J., Shimizu, Y., Eds.; Elsevier: Amsterdam, The Netherlands, 1993; pp. 587-592.

4. IOC. Second IOC Regional Science Planning Workshop on Harmful Algal Blooms in South America; IOC: Mar del Plata, Argentina, 1995; p. 75.

5. Uribe, J.C.; García, C.; Rivas, M.; Lagos, N. First report of diarrhetic shellfish toxins in Magellanic fjord, Southern Chile. J. Shellfish Res. 2001, 20, 69-74.

6. Villarroel, O. Detección de toxina paralizante, diarreica y amnésica en mariscos de la XI región por Cromatografía de Alta Resolución (HPLC) y bioensayo de ratón. Ciencia y Tecnologia del Mar 2004, 27, 33-42.

7. Reguera, B.; Riobó, P.; Rodríguez, F.; Díaz, P.; Pizarro, G.; Paz, B.; Franco, J.; Blanco, J. Dinophysis Toxins: Causative Organisms, Distribution and Fate in Shellfish. Mar. Drugs 2014, 12, 394-461. [CrossRef] [PubMed]

8. Blanco, J.; Correa, J.; Muñíz, S.; Mariño, C.; Martín, H.; Arévalo, F. Evaluación del impacto de los métodos y niveles utilizados para el control de toxinas en el mejillón. Revista Galega dos Recursos Mariños 2013, 3, 1-55. Available online: https:/ / www.researchgate.net/publication/236842103_Evaluacion_del_impacto_de_los_ metodos_y_niveles_utilizados_para_el_control_de_toxinas_en_el_mejillon (accessed on 24 June 2018).

9. Gestal Otero, J.J. Epidemiology of marine toxins. In Seafood and Freshwater Toxins. Physiology, Pharmacology and Detection, 3rd ed.; Botana, L.M., Ed.; CRC Press, Taylor and Francis Group: Boca Ratón, FL, USA, 2014; pp. 123-195.

10. Munday, R. Toxicology of seafood toxins: A critical review. In Seafood and Freshwater Toxins: Pharmacology, Physiology, and Detection; CRC Press, Taylor and Francis Group: Boca Ratón, FL, USA, 2014; pp. 197-290.

11. EFSA Panel on Contaminants in the Food Chain. Marine biotoxins in shellfish-Pectenotoxin group: Marine biotoxins in shellfish-Pectenotoxin group. EFSA J. 2009, 7. [CrossRef]

12. EFSA Panel on Contaminants in the Food Chain. Scientific Opinion of the Panel on Contaminants in the Food Chain on a request from the European Commission on Marine Biotoxins in Shellfish-Summary on regulated marine biotoxins. EFSA J. 2009, 1306, 1-23.

13. Suzuki, T.; Ota, H.; Yamasaki, M. Direct evidence of transformation of dinophysistoxin-1 to 7-O-acyldinophysistoxin-1 (dinophysistoxin-3) in the scallop Patinopecten yessoensis. Toxicon 1999, 37, 187-198. [CrossRef]

14. Doucet, E.; Ross, N.N.; Quilliam, M.A. Enzymatic hydrolysis of esterified diarrhetic shellfish poisoning toxins and pectenotoxins. Anal. Bioanal. Chem. 2007, 389, 335-342. [CrossRef] [PubMed]

15. Torgersen, T.; Sandvik, M.; Lundve, B.; Lindegarth, S. Profiles and levels of fatty acid esters of okadaic acid group toxins and pectenotoxins during toxin depuration. Part II: Blue mussels (Mytilus edulis) and flat oyster (Ostrea edulis). Toxicon 2008, 52, 418-427. [CrossRef] [PubMed]

16. MacKenzie, L.A.; Selwood, A.I.; Marshall, C. Isolation and characterization of an enzyme from the Greenshell (TM) mussel Perna canaliculus that hydrolyses pectenotoxins and esters of okadaic acid. Toxicon 2012, 60, 406-419. [CrossRef] [PubMed]

17. Wilkins, A.L.; Rehmann, N.; Torgersen, T.; Rundberget, T.; Keogh, M.; Petersen, D.; Hess, P.; Rise, F.; Miles, C.O. Identification of fatty acid esters of pectenotoxin-2 seco acid in blue mussels (Mytilus edulis) from Ireland. J. Agric. Food Chem. 2006, 54, 5672-5678. [CrossRef] [PubMed] 
18. Blanco, J.; Alvarez, G.; Uribe, E. Identification of pectenotoxins in plankton, filter feeders, and isolated cells of a Dinophysis acuminata with an atypical toxin profile, from Chile. Toxicon 2007, 49, 710-716. [CrossRef] [PubMed]

19. Avaria, S.; Muñoz, P. Composición y biomasa del fitoplancton marino del norte de Chile en mayo de 1981 (operación oceanográfica MarChile XII-ERFEN III). Ciencia y Tecnología del Mar CONA 1983, 7, 109-140.

20. Avaria, S.; Muñoz, P. Efectos del fenómeno “El Niño" sobre el fitoplancton marino del norte de Chile en diciembre de 1982. Ciencia y Tecnologia del Mar 1985, 9, 3-30.

21. Avaria, S.; Muñoz, P.; Uribe, E. Composición y biomasa del fitoplancton marino del norte de Chile en Diciembre de 1980 (Operación oceanográfica MARCHILE XI-ERFEN II). Ciencia y Tecología del Mar CONA 1982, 6, 5-36.

22. Santander, E.; Herrera, L.; Merino, C. Fluctuación diaria del fitoplancton en la capa superficial del océano durante la primavera de 1997 en el norte de Chile (20 18 S): II. Composición específica y abundancia celular. Revista de Biología Marina y Oceanografía 2003, 38, 13-25. [CrossRef]

23. Faust, M.A.; Gulledge, R.A. Identifying harmful marine dinoflagellates. Contrib. USA Natl. Herb. 2002, 42, 1-144.

24. Lebour, M.V. The Dinoflagellates of Northern Seas; Marine Biological Association of the United Kingdom: Plymouth, UK, 1925; Volume 250.

25. Dodge, J.D.; Hart-Jones, B. Marine Dinoflagellates of the British Isles; Her Majesty's Stationery Office (HMSO): London, UK, 1982.

26. Olenina, I.; Hajdu, S.; Edler, L.; Andersson, A.; Wasmund, N.; Busch, S.; Göbel, J.; Gromisz, S.; Huseby, S.; Huttunen, M.; et al. Biovolumes and Size-Classes of Phytoplankton in the Baltic Sea; Baltic Marine Environment Protection Commission: Helsinki, Filand, 2006.

27. Reguera, B. Biología, Autoecología y Toxinología de las Principales Especies del Género" Dinophysis" Asociadas a Episodios de Intoxicación Diarreogénica por Bivalvos (DSP). Ph.D. Thesis, Universidad de Barcelona, Barcelona, Spain, 2003.

28. Sar, E.A.; Sunesen, I.; Lavigne, A.; Goya, A. Dinophysis spp. asociadas a detección de toxinas diarreicas (DSTs) en moluscos y a intoxicación diarreica en humanos (Provincia de Buenos Aires, Argentina). Revista de Biología Marina y Oceanografía 2010, 45, 451-460. [CrossRef]

29. Fabro, E.; Almandoz, G.O.; Ferrario, M.; Tillmann, U.; Cembella, A.; Krock, B. Distribution of Dinophysis species and their association with lipophilic phycotoxins in plankton from the Argentine Sea. Harmful Algae 2016, 59, 31-41. [CrossRef] [PubMed]

30. Suzuki, T.; Mackenzie, L.; Stirling, D.; Adamson, J. Pectenotoxin-2 seco acid: A toxin converted from pectenotoxin-2 by the New Zealand Greenshell mussel, Perna canaliculus. Toxicon 2001, 39, 507-514. [CrossRef]

31. Suzuki, T.; Mackenzie, L.; Stirling, D.; Adamson, J. Conversion of pectenotoxin-2 to pectenotoxin-2 seco acid in the New Zealand scallop, Pecten novaezelandiae. Fish. Sci. 2001, 67, 506-510. [CrossRef]

32. Miles, C.O.; Wilkins, A.L.; Munday, R.; Dines, M.H.; Hawkes, A.D.; Briggs, L.R.; Sandvik, M.; Jensen, D.J.; Cooney, J.M.; Holland, P.T.; et al. Isolation of Pectenotoxin-2 From Dinophysis acuta and Its Conversion to Pectenotoxin-2 Seco Acid, and Preliminary Assessment of Their Acute Toxicities. Toxicon 2004, 43, 1-9. [CrossRef] [PubMed]

33. Burgess, V.; Shaw, G. Investigations into the Toxicology of Pectenotoxin-2-Seco Acid and 7-Epi Pectenotoxin 2-Seco Acid to Aid in a Health Risk Assessment for the Consumption of Shellfish Contaminated with These Shellfish Toxins in Australia; Report on Project No. 2001/258; Fisheries Research and Development Corporation: Canberra, Australia, 2003; ISBN 0975025910.

34. Suzuki, T.; Mitsuya, T.; Matsubara, H.; Yamasaki, M. Determination of pectenotoxin-2 after solid-phase extraction from seawater and from the dinoflagellate Dinophysis fortii by liquid chromatography with electrospray mass spectrometry and ultraviolet detection. Evidence of oxidation of pectenotoxin-2 to pectenotoxin-6 in scallops. J. Chromatogr. A 1998, 815, 155-160. [CrossRef] [PubMed]

35. Suzuki, T. Chemistry and Detection of Okadaic Acid/Dinophysistoxins, Pectenotoxins and Yessotoxins. In Toxins and Biologically Active Compound from Microalgae. Vol 1 Origin, Chemistry and Detection; Rossini, G.P., Ed.; CRC Press: Boca Raton, FL, USA, 2014; pp. 99-152.

36. Rossignoli, A.E.; Fernandez, D.; Regueiro, J.; Marino, C.; Blanco, J. Esterification of okadaic acid in the mussel Mytilus galloprovincialis. Toxicon 2011, 57, 712-720. [CrossRef] [PubMed] 
37. Marr, J.C.; Hu, T.; Pleasance, S.; Quilliam, M.A.; Wright, J.L.C. Detection of new 7-O-acyl derivatives of diarrhetic shellfish poisoning toxins by liquid chromatography-mass spectrometry. Toxicon 1992, 30, 1621-1630. [CrossRef]

38. Morohashi, A.; Satake, M.; Murata, K.; Naoki, H.; Kaspar, H.F.; Yasumoto, T. Brevetoxin B3, a new brevetoxin analog isolated from the greenshell mussel Perna canaliculus involved in neurotoxic shellfish poisoning in new zealand. Tetrahedron Lett. 1995, 36, 8995-8998. [CrossRef]

39. Aasen, J.A.; Hardstaff, W.; Aune, T.; Quilliam, M.A. Discovery of fatty acid ester metabolites of spirolide toxins in mussels from Norway using liquid chromatography/tandem mass spectrometry. Rapid Commun. Mass Spectrom 2006, 20, 1531-1537. [CrossRef] [PubMed]

40. De la Iglesia, P.; McCarron, P.; Diogene, J.; Quilliam, M.A. Discovery of gymnodimine fatty acid ester metabolites in shellfish using liquid chromatography/mass spectrometry. Rapid Commun. Mass Spectrom. 2013, 27, 643-653. [CrossRef] [PubMed]

41. Janer, G.; Lavado, R.; Thibaut, R.; Porte, C. Effects of $17 \beta$-estradiol exposure in the mussel Mytilus galloprovincialis: A possible regulating role for steroid acyltransferases. Aquat. Toxicol. 2005, 75, 32-42. [CrossRef] [PubMed]

42. Janer, G.; Mesia-Vela, S.; Porte, C.; Kauffman, F.C. Esterification of vertebrate-type steroids in the Eastern oyster (Crassostrea virginica). Steroids 2004, 69, 129-136. [CrossRef] [PubMed]

43. Furumochi, S.; Onoda, T.; Cho, Y.; Fuwa, H.; Sasaki, M.; Yotsu-Yamashita, M.; Konoki, K. Effect of carbon chain length in acyl coenzyme A on the efficiency of enzymatic transformation of okadaic acid to 7-O-acyl okadaic acid. Bioorg. Med. Chem. Lett. 2016, 26, 2992-2996. [CrossRef] [PubMed]

44. Blanco, J.; Fernández, M.L.; Míguez, A.; Moroño, A. Okadaic acid depuration in the mussel Mytilus galloprovincialis: One- and two-compartment models and the effect of environmental conditions. Mar. Ecol. Prog. Ser. 1999, 176, 153-163. [CrossRef]

45. Moroño, A.; Arévalo, F.; Fernández, M.L.; Maneiro, J.; Pazos, Y.; Salgado, C.; Blanco, J. Accumulation and transformation of DSP toxins in mussels Mytilus galloprovincialis LMK during a toxic episode caused by Dinophysis acuminata. Aquat. Toxicol. 2003, 62, 269-280. [CrossRef]

46. Lindegarth, S.; Torgersen, T.; Lundve, B.; Sandvik, M. Differential Retention of okadaic acid (OA) group toxins and pectenotoxins (PTX) in the blue mussel, Mytilus edulis (L.), and european glat oyster, Ostrea edulis (L.). J. Shellfish Res. 2009, 28, 313-323. [CrossRef]

47. Vale, P. Differential Dynamics of Dinophysistoxins and Pectenotoxins Between Blue Mussel and Common Cockle: A Phenomenon Originating From the Complex Toxin Profile of Dinophysis acuta. Toxicon 2004, 44, 123-134. [CrossRef] [PubMed]

48. Valle-Levinson, A.; Moraga, J.; Olivares, J.; Blanco, J.L. Tidal and residual circulation in a semi-arid bay: Coquimbo Bay, Chile. Cont. Shelf Res. 2000, 20, 2009-2028. [CrossRef]

49. Berríos, M.; Olivares, J. Caracterización granulométrica y contenido de carbono orgánico de los sedimentos marinos superficiales, en el sistema de bahías de la IV Región. Coquimbo. Cienc. Tecnol. Mar. 1996, 19, 37-45.

50. Fritz, L.; Triemer, R.E. A rapid simple technique utilizing calcofluor white M2R for the visualization of dinoflagellate thecal plates. J. Phycol. 1985, 21, 662-664. [CrossRef]

51. Hasle, R.G. The inverted microscope method. In Phytoplankton Manual; UNESCO: Paris, France, 1978; pp. 88-96.

52. EURLMB. EU-Harmonised Standard Operating Procedure for Determination of Lipophilic Marine Biotoxins in Molluscs by LC-MS/MS. Version 5. Available online: http://aesan.msssi.gob.es/CRLMB/docs/ docs/metodos_analiticos_de_desarrollo/EU-Harmonised-SOP-LIPO-LCMSMS_Version5.pdf (accessed on 30 June 2015).

53. Regueiro, J.; Rossignoli, A.E.; Alvarez, G.; Blanco, J. Automated on-line solid-phase extraction coupled to liquid chromatography tandem mass spectrometry for determination of lipophilic marine toxins in shellfish. Food Chem. 2011, 129, 533-540. [CrossRef]

54. R Core Team. R: A Language and Environment for Statistical Computing; R Foundation for Statistical Computing: Vienna, Austria, 2014.

55. Wickham, H. Ggplot2: Elegant Graphics for Data Analysis; Springer: New York, NY, USA, 2016.

(C) 2018 by the authors. Licensee MDPI, Basel, Switzerland. This article is an open access article distributed under the terms and conditions of the Creative Commons Attribution (CC BY) license (http:/ / creativecommons.org/licenses/by/4.0/). 